\title{
The urban features of the formation of the ensemble development of the kyiv-pechersk lavra (the latter half of the $17^{\text {th }}-18^{\text {th }}$ centuries)
}

\begin{abstract}
Significant development of monastic construction in the Naddnipryanshchyna (the Dnipro Ukraine), Livoberezhzhia (the Left-bank Ukraine) and Slobozhanshchyna (Sloboda Ukraine) during the time of the Hetmanate had a solid socio-political background, the main of which was the liberation from the national and religious oppression and the formation of statehood. The economic conditions were no less important. The economic power of the monasteries allowed to rebuild the ancient monasteries, which already had brick buildings, rebuilt the ancient monasteries that were entirely wooden to the masonry ones.

The subject of the formation of stone building on the territory of the Kyiv-Pechersk Lavra in the $17^{\text {th }}-18^{\text {th }}$ centuries is of exceptional interest for research, as it is the only architectural ensemble, united by unique monuments, which has no analogues in the Ukrainian architecture.
\end{abstract}

Key words: urban aspect, Orthodox monasteries, the Kyiv-Pechersk Lavra

\section{Introduction}

According to historical experience, a large number of architectural monuments was built considering the natural environment, and when it comes to religious buildings of the Hetmanate in the lands of the Dnipro and the Left-bank Ukraine, they tried to locate them on the most picturesque high-rise sites, with the possibility of viewing them from afar, and in the presence of water files - rivers, lakes, ponds - with the inclusion of them in the general composition [7-9]. A typical example of the Hetmanate's time is a temple or monastic ensemble situated on a high bank of a river or on a hill above a lake, surrounded by greenery, at a certain distance from the background development [7-9]. The temple building kept the same tradition in the future.

For example, St.Sophia Monastery, St. Andrew's Church, Three Saints Church, St. Michael's GoldenDomed Monastery, Upper and Lower Lavra, Trinity Monastery of St. Jonas, Vydubychi Monastery in Kyiv were built on rising ground [7-9]. Often the existence of ancient caves in the mountains was an additional factor for the location of the monastery [12].

Thus, the monastery was often officially founded in the days of the Hetmanate, and the settlements in this place or the caves of the hermits in the mountains could have existed since ancient times, which was explained by a combination of favorable factors: rising ground (protection and complete inspection - defense function), availability of water (water supply, fish farming, river transport - life support and trading function), favorable climate, soils (agricultural function). An example is the location of St. Michael's GoldenDomed Monastery, the Upper and Lower Lavra, Vydubychi Monastery [4, 10-13]. It is precisely in the time of the Hetmanate that the prosperity of Orthodoxy begins after years of long unfavorable Uniate domination. In the days of the Hetmanate until the days of Catherine the Great, who began the policy of secularization - the removal of the monastery land into the state treasury the monasteries and temples were the richest landowners who had plough lands, vegetable plots, gardens, apiaries, lakes and hayfields.

\section{Characteristics of the urban ensemble of the} Kyiv-Pechersk Lavra.

As already noted, the Kyiv-Pechersk Lavra occupies a special place among the ensemble development of the Hetmanate.

The periodization of the planning and compositional structure of this complex should be determined. The town-planning basis of the Upper Lavra ensembles, the territories of the Near and Far Caves, the Pechersk town with their boundaries, check points, planning and spatial links, which had been defined in previous times, was preserved in the Mazepa period. As before, there is a clear functional division of the territory into a residential 
The defensive wall surrounding the Lavra made the monastery similar to the city, emphasizing its selfsufficiency, symbolizing the border between two worlds - the ecclesiastic and the secular. The fence was associated with salvation, with isolation from sin. Monastery walls thus served not only the defensive purpose, but also symbolized the paradise seclusion of monastic life.

Like other Orthodox monasteries, the Kyiv-Pechersk Like ohtery featured a large number of Kyivechersk Mover, the Dormition Cathedrat, which played a leading ever, in Dor in size (vold en in size (volume and height), location (in the center of the freely on square squed freely on the square, his temple, in accordance with the town-planning and ensemble principles of the Ukrainian Baroque Ortodox temple building, had an "rallfacaden of a dimensional solution. As an accentuating link in the composition of the Cathedral square, it was located asymmetrically with respect to the main axis, which created an extremely picturesque effect. Occupying a central position in the system of monastic development, the temple determined at the same time the direction of the main visual axes and the attitude of the Holy Gates to the entrance to it.

Like in all Orthodox monastic complexes, the second most important after the cathedral was the building of the Refectory. It was associated with the Lord's Supper and had a mystical meaning, therefore, was not interpreted as a utilitarian structure, but functionally, figuratively and compositionally tended towards the cathedral temple. This value of the Refectory is reflected in a special temple built in it. The location of the Refectory was connected with the features of the monastic order and ritual.

A complex of buildings belonging to the Refectory (church and kitchen) in the Kyiv-Pechersk Monastery was located on the southwestern side of the Dormitio Was located on the sold Russian times. The ruins of these buildings are mentioned in 1584 by Mertin Gro these buldings in the Old Rus He also mentions ma great beautin wooden house" a new Refectory where nons gathered for a holiday and where Grunew "s was ither big Refead and honey. In 1638 there was the rather big Refectory, the warm church in it, named after the holy Apostles Peter and Paul» in the monastery and along with it «the gate to the brethren kitchens and the Archimandrite kitchen on the south or southwestern side of the Dormition Cathedral.

On the plan of 1638, the Refectory is a rectangula structure, in plan view completed by four stepped high pediments that cover the edges of high saddle roofs, directed across the length of the building. After the stone old Russian Refectory ceased to function, these structures were wooden for a long time. Only during the days of Hetman I. Samoilovych the work on their replacement into the stone ones started. This work lasted quite a long time and was completed only in
1694. Construction was carried out at the expense of Kyiv citizen Mykhailo Maksymovych. On the plan of 1695 the complex of stone buildings of the Refectory is shown as complete. The Refectory church and the chamber, as well as the kitchen room were damaged during the fire of 1718 , but they were quickly repaired, according to the report of 1721 to the governor of Kyiv.

The complex of reconstructed buildings consisted of three parts: a small temple in the name of the Holy Apostles Peter and Paul, a the name of the in plan view two-story refectory on the west side of it and service roty refectory on the west outh. Therve bulding we the 1040's of the $18^{\text {th }}$ century a one only building wo rooms was attached to them.

\section{Bell Tower as a town-planning dominant}

of the monastic ensemble

An integral component of every Orthodox monastic complex was the bell tower. As a rule, it was rected over the main gate or near the temple. I Kyiv-Pechersk Monastery the bell towers were always located near the Dormition Cathedral. In the first half of the $17^{\text {th }}$ century two bell towers rose near the western facade of the main church on the Cathedral Square, described at one time by Paul of Aleppo.

Regarding the location of the bell tower in the complex, two fundamental solutions are known:

1. Above the main gate (Maksakivsk Monastery, Hamaliivsk Monastery, in Kyiv - St. Sophia, Vydubych and St. Michael's Golden-Domed monasteries): 2. Near the Cathedral Church (Kyiv-Pechersk Lavra, Kozeletsk St. George Monastery).

However, by the middle of the $18^{\text {th }}$ century the oll towers, being important vertical accents the sitional role, and Iways were dominated by the cathedral.

The Bell Tower was an important vertical accent in monastic building and played a significant compositional role in it. And yet, as bell towers of ther monasteries of that time, it did not exceed the main temple. Judging by the image of the Bell Tower in the panorama of the monastery by Athanasius the Clericus in 1677 and "Drawing" by 1. Ushakov in 1695, its height was lower than the central dome of the Dormition Cathedral and was about $40 \mathrm{~m}$.

During the fire of 1687 the Bell Tower, probably, was not significantly damaged, but the active process of replacing wooden monastery buildings with stone ones, started at the end of the $17^{\text {th }}$ century, could not ignore such an important building as the main Bell Tower. The Hetman and the authority of the monastery had a desire to build a new stone

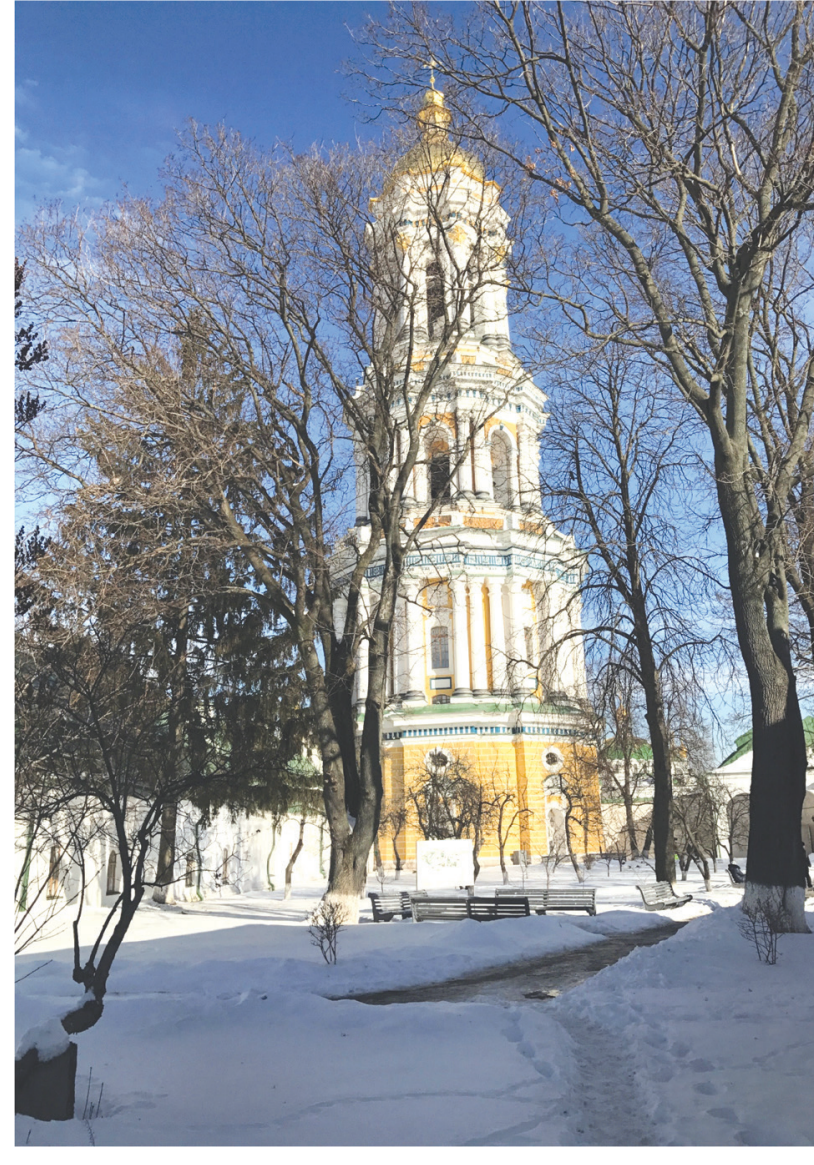

III. 3. Bell tower. Fot. O. Chobitko

bell tower, taking into account the needs and tastes of that time.

These works were entrusted to the Moscow architect D.V. Aksamytov, who then worked in Ukraine. But the planned construction of a stone bell tower in the days of Hetman I.S. Mazepa was not implemented. Aksamyto had only laid the foundations, but soon after that h died, and only in 1731 the erection of the Great Lavra Bell Tower began by architect G. Schädel, which lasted until 1745. It is a faceted, four-tier of classical order: the first tier has rustic walls; the next tiers are accented with columns, order of which is visually lightened from up: from the Roman-Doric order to the Corinthian.

4. Additional buildings of the monastic ensemble and methods for planting of greenery at the monastery erritory

"Archimandrite's chambers" were situated to the west of the complex of the Refectory.

Archimandrite's garden was located behind the archimandrite's chambers within the monastery wall around the Upper Lavra. The garden was represented in the Christian world as a paradise on earth, Eden. Trees, shrubs and flowers were symbolic and allegorical in it. So, in the monastery garden, every plant and every de- tail reminded us of the foundations of divine homebuilding, of Christian virtues.

Gardens of that era in aesthetic terms were subject to architecture, which involved, in particular, building there the main walls of terraces, stairs, railings. Gardeners took care to open the views at the surroundings - from windows, terraces, garden sites. This style is characterized by the desire to create scenery from greenery, combining them with invisible transitions with architecture.

A stone cell of kvass (rye beer) brewers «with A stone cell of kvass (rye beer) brewers "with A stors cell of kvass (rye beer) brewers iwith

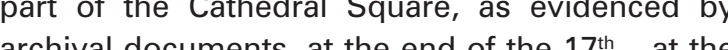
begining of the $18^{\text {th }}$ centuries In the volume the begial composition cathedal Squere, and spatial composition the Cathedral Square, closing the perspective that opened from the main gate, was flanked in the east with a complex of building of a Print-house and a Bakery. There was the Lavr

After the construction of the monastery wall and the appearance of the gates with the Church of All Saints, a broad street, which leads to the north of the Dormition Cathedral and called "economicn, was gradually formed in the northern fronts of the fence. The perspective was completed by the Church of the Saviour at Berestovo.

\section{Formation of the ensemble development}

of the Lower Lavra (Near and Far Caves)

In the period under consideration, certain changes had taken place in the development over the Near ritory of the Near Caves on the plan of the monastery of 1638 with the Lavra drawing, traditionally dated 1651, one can conclude that the wooden Church of the Exaltation of the that the wooden entrats of the Holy Cross over the is, probably, in the days of the metropolitan Petro Mohyla.

At the engraving of Elijah (1655-1658) to the «KyivPechersk Patericon", published in 1661 and 1674, the Church of the Exaltation of the Holy Cross, which occupied a dominant position in architectura ensemble of the Near Caves, is depicted in the form of a wooden temple with two tops: above the altar and the nave.

On the "Drawings" of I. Ushakov the Church of the Exaltation of the Holy Cross was already recorded as a stone one. Presumably, it was built in the time of the Hetman I. Samoilovych. That is, the widespread belief that the stone church was built here in 1700 is not true. This was confirmed by the field studies of the monument, performed in 1985 . Thus, the analysis of the brick mural of the monument has allowed to set such a sequence of construction of different volumes of the building. At 
ed below [4, 10-13]. This provided a certain Orthodox church hierarchy: the Dormition Cathedral - the House of the Mother of God is a unique temple both for the value for all Eastern Orthodoxy and for Ukraine, and for the history and architecture, so everyone who drove up to Kyiv from the sloping left bank, immediately understood which temple is the main in the Lavra: it was emphasized by the nearby baroque multi-tiered Bell Tower, which was the tallest building in Kyiv for centuries [13]. And here we come to the main contradiction of the location of temples in previous ages: on the one hand, they sought to place them in the highest place, but did not take into account the presence of landslides and groundwater. Therefore, the main cause of the state of emergency and damage, the collapse of parts of all the temples of the upper edge of the right bank were the subsidence of bases and foundations, water-saturation of loess soils and, consequently, the appearance of cracks $[5,6,13]$.

\section{BIBLIOGRAPHY}

[1] Vecherskyi V. Arkhitekturna i mistobudivna spadshchyna doby Hetmanshchyny. Formuvannia, doslidzhennia, okhorona [Architectural and Urban Heritage of the Hetmanate. Formation, Research, Protection]. Kyiv, 2001. 350 p. [in Ukrainian].

[2] Vecherskyi V Spadshchyna mistobuduvannia Ukrainy: Teoriia i praktyka istoryko-mistobudivnykh pamiatkookhoronnykh doslidzhen naselenykh mists [Heritage of Urban Planning in Ukraine: Theory and Practice of Historic and Urban Researches of Populated Areas]. Kyiv, 2003. 400 p. [in Ukrainian].

[3] Vecherskyi V. Ukrainski monastyri [Ukrainian Monasteries]. Kyiv, 2008. 400 p. [in Ukrainian].

[4] Ivashko Yu.V. Baroque style in the architecture of Ukrainian churches. Liudyna i svit [Man and the World], 1997, No 11-12, pp. 12-15. [in Ukrainian].

[5] Istoryko-mistobudivni doslidzhennia Kyieva [Historical and Urban Studies of Kyiv]. Vecherskyi V. V. (Ed); Serdiuk O.M. (Rel). Kyiv, 2011. 454 p. [in Ukrainian].

Translator-Mariia Buiuli

Foto - Chobitko Oksana 